detection system, target DNA was amplified within $30 \mathrm{~min}$ under isothermal conditions. Six primers were designed using Primer Explorer Ver. 3.0 (Fujitsu, Tokyo, Japan). The LAMP reaction was performed with a Loopamp DNA amplification kit (Eiken Chemical, Tokyo, Japan). The reaction mixture containing primers, reaction mix, Bst DNA polymerase, and chromosomal DNA was incubated at a constant temperature. Without gel electrophoresis, the LAMP amplicons were visualized directly in the reaction tube on adding SYBR Green I for naked-eye inspection. In addition, quantitative detection using the LAMP technique is available by measuring the precipitation of magnesium pyrophosphate, a by-product of the LAMP reaction. Moreover, LAMP assays were applied to clinical samples of subgingival plaque and the results were almost identical to those using conventional PCR, but had the advantage of rapidity. These results indicate that the LAMP assay is an extremely rapid, highly sensitive, and specific method. This method is very useful for the rapid detection of periodontopathic pathogens and the diagnosis of periodontal disease.

\title{
$\mathrm{P}-10$. 電解研磨による歯科用チタン鏡面研磨の可能性の検討
}

○田島 清司·永松 有紀·杮川 宏·小園 凱夫 九歯大 - 生体材料

今回新たに開発された，アルコール系電解液を用い電解液の攪拌機能を備えた電解研磨装置を用いて，チタンの電 解研磨を行い，研磨面の試料外観，表面粗さ测定，SEM よる表面観察などにより検討を加えた。 その結果，電解液 を攪拌しながら電解研磨を行う装置とアルコール系電解液を用いて研磨条件（浴温度および電解電圧）を最適化する ことで，純チタン执よびチタン合金加工材の鏡面研磨仕上げが可能であることが明らかになった，一方，純チタン鋳 造材では光輝面は得られたが, 加工材ほよ゙の光沢鏡面は得られず, 表面粗さむ大きかった，これには前処理サンドブ ラストの種類や鋳造に起因した研磨面の析出層の影響が考えられた. 今後, チタン鋳造体の電解研磨には鋳造条件や 電解時間と研磨量の関係などを検討する必要があるものと思われる.

A study of the possibilities for electro-polishing of dental titanium for mirror-polishing

Kiyoshi Tajima, Yuki Nagamatsu, Hiroshi Kakigawa and Yoshio Kozono (Division of Biomaterials, Kyushu Dental College)

$\mathrm{P}$ - 11. チタンと非接触状態で共存する異種合金の腐食

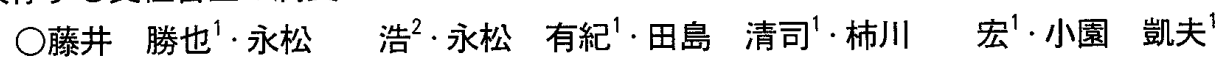

${ }^{1}$ 九歯大·生体材料, ${ }^{2}$ 九歯大·総診

歯科臨床において，対合歯や隣接歯の修復に異種合金を用いると，それらの接触がガルバニ腐食やガルバニショッ クの原因になる。演者らは, チタンと歯科用合金が乳酸水溶液中で非接触状態で共存した場合の腐食挙動を調べて, 合金単独での浸漬およびチタンと接触して浸漬した場合と比較した．チタンとの共存（接触·非接触）で，金合金， 白金加金は溶出挙動に影響がなく, 金銀パラジゥム合金では, $\mathrm{Ag}$ の溶出抑制, $\mathrm{Cu}$ の溶出促進がみられた. 銀合金は 単独でも $\mathrm{Ag}, \mathrm{Zn}$ 等の溶出が著しかったが, チタンとの共存で明確な影響はなかった。コバルトクロム合金は, 共存 でCoの溶出促進がみられた. チタンからの Ti の溶出は, 銀合金との共存で抑制, 白金加金では変化なし, 他の合金 では，溶出促進の傾向がみられたが，接触と非接触で有意差はなかった，非接触でも接触と同じく合金の腐食が起こ りえるため，臨床で同一口腔内に異種合金を使用する場合は，部位が離れていてあ慎重に合金を選択する必要がある ことが示唆された。

\section{Corrosion of titanium and other coexisting dental alloys out of contact}

Katsuya Fujii ${ }^{1}$, Hiroshi Nagamatsu', Yuki Nagamatsu ${ }^{1}$, Kiyoshi Tajima ${ }^{1}$, Hiroshi Kakigawa ${ }^{1}$ and Yoshio Kozono ${ }^{1}$ (Division of Biomaterials and ${ }^{2}$ Division of Comprehensive Dentistry, Kyushu Dental College)

The present study examined the potential electrochemical corrosion between titanium and coexisting dental alloys during 36 weeks in cases of single immersion and pairs in contact and noncontact. No 
or little changes was seen in dissolutions of $\mathrm{Au}-\mathrm{Ag}-\mathrm{Cu}$ and $\mathrm{Au}-\mathrm{Pt}-\mathrm{Pd}$ alloys even if immersed in couple with the titanium specimen being in contact or out of contact. The amount of dissolved Ag decreased and that of $\mathrm{Cu}$ increased in $\mathrm{Au}-\mathrm{Ag}-\mathrm{Pd}$ alloy specimen when coexisted with pure titanium specimen. Marked dissolutions of $\mathrm{Ag}, \mathrm{Zn}, \mathrm{Sn}$ and In were found from $\mathrm{Ag}-\mathrm{Zn}$-Sn-In alloy specimen even if immersed alone. From $\mathrm{Co}-\mathrm{Cr}$ alloy, Co was most dissolved among the constituents and acceleratedly dissolved by coexisting with pure titanium specimen. The amount dissolved Ti decreased by coexisting with $\mathrm{Ag}-\mathrm{Zn}-\mathrm{Sn}-\mathrm{In}$ alloy specimen. On the other hand, an increased amount of dissolved Ti was found by coexisting with $\mathrm{Au}-\mathrm{Ag}-\mathrm{Cu}$ and $\mathrm{Au}-\mathrm{Ag}-\mathrm{Pd}$ alloys.

\section{$P$ - 12. モロヘイヤ粉末を用いた歯磨材の有効性}

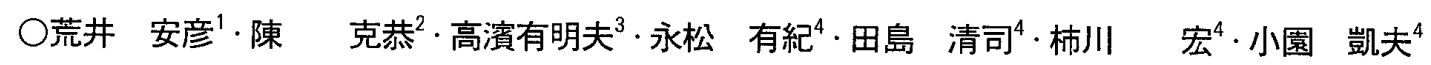
${ }^{1}$ 森善株式会社, ${ }^{2}$ 九歯大 $\cdot$ う蝕制御, ${ }^{3}$ 九歯大·総合教育, ${ }^{4}$ 九歯大·生体材料

モロヘイヤはビタミンやカロテン, カルシウムを多く含む食材として注目され, サプリメントとして粉末状でも市 販されている. 本研究ではモロへイヤの歯垢·歯石除去効果の特許に基づき, 室温で超乾燥後粉砕したモロへイヤ粉 末を用い, 研磨材, 発泡剤, フッ素を含まない歯磨材の実用化に向けてその有効性を調べた. $10 \mathrm{wt} \%$ $\%$ ロへイヤ粉 末と水道水との混合液中に歯垢·歯石の付着が認められる抜去歯を浸漬し, 色差計を用いてエナメル質表面の変化を 観察した。その結果，浸漬だけで経時的に色差が増大し，5週目で歯垢·歯石の一部が除去されるとともに，浸漬前 と比較して顕著な色調の変化が認められた．これは，主としてェナメル質表面の歯垢の除去に伴って明度および光沢 が増したことによるあのであった。 また，使用したモロへイヤは蛍光分析により活性窒素の生成抑制作用を示すこと がわかった，以上の結果から，モロへイヤを主要成分とする歯磨材は，研磨材を含まなくてす高い㐘磨効果を示すだ けではなく，モロへイヤの強い抗酸化作用によってロ腔内での活性酸素, 活性窒素の生成を抑制しあるいは消去する 効果も期待される.

\section{The usefulness of Mulukhiya powder as a tooth cleaner}

Yasuhiko Arai, Ker-Kong ${ }^{1}$ Chen ${ }^{2}$, Umeo Takahama ${ }^{3}$, Yuki Nagamatsu', Kiyoshi Tajima ${ }^{4}$ Hiroshi Kakigawa ${ }^{4}$ and Yoshio Kozono ${ }^{4}$ ( ${ }^{1}$ Morizen CO., LTD., ${ }^{2}$ Division of Pulp Biology, Operative Dentistry and Endodontics, ${ }^{3}$ Division of General Education and ${ }^{4}$ Division of Biomaterials, Kyushu Dental College)

Mulukhiya, a kind of vegetables, is rich in vitamins, carotene, calcium, etc., and its powdered form has been put on the market as a supplemental food. On the basis of the patent for its ability to remove calculi and stains, in this study the actual usefulness of Mulukhiya powder for tooth cleaning was examined to develop a new toothpaste without abrasives. Extracted teeth with calculi and stains were selected and immersed in Mulukhiya slurry for 5 weeks and the changes in surface appearance were colorimetrically observed. The color difference from the control significantly increased as the immersion period increased. Specifically, the brightness and luster of the enamel improved, which might be mainly due to the partial removal of stains. Calculus dislodgement was also observed. These findings indicate that Mulukhiya may be a good component for tooth cleaners without abrasives. In addition, it is expected that Mulukhiya may inhibit the generation of activating oxygen and activating nitrogen or eliminate them due to its marked anti-oxidation properlies.

$\mathrm{P}$ - 13. 唾液分泌刺激に伴う $\gamma$-グルタミルトランスペプチダーゼのラット舌下腺細胞内局在変化

○増田 渉·自見英治郎

九歯大·生化学

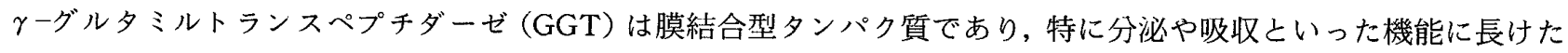
細胞に多く存在している. 本研究では, ラット舌下腺 GGT の唾液分泌刺激（交感·副交感神経刺激）による細胞内局 在変化を, ショ糖密度勾配遠心法を用いて検討した，基底側膜，管腔側膜，分泌顆粒のマーカー分子としてそれぞれ 